Research Article

\title{
In vitro Studies on Pollen Viability, Pollen Germination and Pollen Tube Growth of Hornstedtia conoidea Ridl. - a Philippine Endemic Ginger Species
}

\author{
Noe Polo Mendez ${ }^{1,2} *$, Florfe Macabudbud Acma ${ }^{1,2}$ \\ ${ }^{1}$ Department of Biology, College of Arts and Sciences, Central Mindanao University, University Town, \\ Musuan, Bukidnon 8710, Philippines \\ ${ }^{2}$ Center for Biodiversity Research and Extension in Mindanao (CEBREM), Central Mindanao University, \\ University Town, Musuan, Bukidnon 8710, Philippines
}

Article history:

Submission June 2018

Revised September 2018

Accepted September 2018

*Corresponding author:

E-mail: npolomendez@gmail.com

\begin{abstract}
Zingiberaceous plants are predominantly propagated through underground rhizomes and seeds. In this study, the viability of pollen, rate of pollen germination and length of pollen tube of the Philippine endemic Hornstedtia conoidea were examined. Four petri plates containing pollen samples were prepared, of which two petri plates were used immediately after the collection, while the other two petri plates were stored for one week. The determination of pollen viability was made employing stain tests using IKI (iodine + potassium iodide) solution and safranin and measured immediately after the collection and after one week. Likewise, pollen germination test was carried out in vitro on agar medium and measured after 24 hours and one week of incubation. Data revealed that pollen viability was higher in the samples which were sown immediately with safranin with percentage pollen viability of $92.43 \%$, while IKI test was lower with $89.36 \%$. On the other hand, the pollen stored for one week measured $47.29 \%$ for safranin test and $33.14 \%$ for IKI test. The percentage germination of pollen after 24 hours was $72.65 \%$, while $11.13 \%$ after one week. The pollen samples which were subjected for tube growth were examined for two weeks and gave positive results. Overall, it can be concluded that $H$. conoidea pollen can successfully be collected and stored for certain time. Knowledge regarding the pollen viability, pollen germination and pollen tube growth of this species will give practical benefit for plant breeding and conservation purposes, since $H$. conoidea is found in the wild, and as of now, the species has been recorded only in the Philippines.
\end{abstract}

Keywords: Ethno-medicinal uses, native species, palynology, "tagbak”, Zingiberaceae

\section{Introduction}

The ginger family (Zingiberaceae) consists of herbaceous perennial plants that grow well in humid tropical and subtropical areas and are mostly distributed in Southeast Asia [1]. Furthermore, Zingiberaceous plants are animal-pollinated tropical monocotyledons and display a broad range of pollination and breeding systems [2, 3]. In the Philippines, this family is represented with 16 known genera [4]. One of these is Hornstedtia Retz., which is characterized by a rigid spindleshaped inflorescence composed of many sterile bracts often with reticulate nervation [5]. Hornstedtia conoidea Ridl., a Philippine endemic ginger species and known for its local name tagbak is the most abundant Philippine Hornstedtia species in the Province of Bukidnon and other areas of Mindanao. Seeds from its ripe fruits are edible and eaten by the local people in the said Province and claimed to cure stomach disorders [6].

Pollen are immature endosporic male gametophytes of seed plants which produce the male gametes or sperm cell and are found in the reproductive organ of the plant which is necessary for 
the angiosperm species to reproduce sexually [7, 8]. Estimation of pollen viability is useful for plant breeders and geneticists in eliminating the time and space problems [9] and can be made using direct methods such as the induction of in vitro pollen germination $[10,11]$. The assessment of pollen quality by its in vitro germination is a useful method for determining the acceptability of pollen for artificial pollination [12]. Furthermore, studies of in vitro pollen germination and pollen tube growth are important for understanding fertilization and seed formation in flowering plants and are very useful for explaining any lack of plant fertility [13].

The importance of pollen in reproduction for the continuity of the species must be addressed. Since $H$. conoidea is endemic to the Philippines and used by the local people as food and alternative medicine, there might be odds that an over collection of its fruits and rhizomes could decline its populations without efforts to propagate. Thus, this study was undertaken to examine its pollen viability, pollen germination and pollen tube growth to contribute understanding and to provide insights to plant physiologists, plant breeders and conservationists on the horticultural practice of its reproduction. Furthermore, the updated distribution and ethno-medicinal uses of $H$. conoidea are also provided herein.

\section{Material and Methods \\ Collection of pollen samples}

Fresh hermaphrodite flowers of $H$. conoidea were collected early in the morning from 20 plant individuals of the same population. The collection was done during the anthesis of the flowers at Acma's residence of Market Site of Central Mindanao University, Musuan, Bukidnon from November 2015 to February 2016. The collected flowers were placed in zip-lock cellophane bags to prevent drying and brought immediately to the laboratory. Pollen samples were collected from matured stamens and placed in four separate petri plates. Two petri plates were sown immediately with pollen for testing the presence of starch, pollen viability, pollen germination and pollen tube growth, while the other two petri plates were stored in the laboratory at a maintained temperature of $20^{\circ} \mathrm{C}$ and were also sown with pollen for the same tests (except for testing the presence of starch) one week after incubation.

\section{Pollen viability}

For determining the presence of starch, fresh pollen samples were mounted on glass slides and tested with a drop of IKI (iodine + potassium iodide) solution. As reported by several studies, pollen viability can be assessed by staining and direct count. Hence, another set of pollen samples for the determination of the pollen viability were prepared separately using a drop of IKI solution and safranin and enclosed with cover slips. Each slide was examined under microscope to determine counts of viable and inviable pollen. The viability test was also done after one week using the stored pollen. Pollen samples which turned brown or black were scored as fertile, whereas pollen which remained colorless or less colorful were scored as infertile. Calculation of percentage pollen viability was determined using three replicates from about 200 samples each.

\section{In vitro pollen germination}

Under natural conditions, pollen of different species often require specific media for germination $[14,15]$. In this study, the germinating medium of Karni and Aloni [16] with modifications by Reddy and Kakani [17] was used since it gave positive results to the other ginger species examined by Mendez et al. [18]. The experiments were conducted in vitro conditions using agar plate method. An estimated $10 \mathrm{~mL}$ of germinating medium was dispensed into three sterilized petri plates. Pollen were sprinkled on the medium by brushing on each petri plate. The whole procedure was completed within 30 minutes to avoid pollen desiccation. Experiment was done in a completely randomized design (CDR) with three replicates and selected independently in the slide to avoid duplication. Pollen germination percentage and pollen tube length were measured under light microscope $(100 \times)$ examined from 10 randomized selected squares after $24 \mathrm{~h}$ of incubation. The same procedure was done on the one-week old stored pollen. The pollen was classified as germinated if at least the beginning of a developing tube could be seen emerging from one of the pores or reach its diameter $[19,20]$. The percentage of pollen germination for each petri plate was calculated [14, $21,22]$. For each reading, 200 pollen were counted and scored as germinated or ungerminated depending on whether an intact pollen tube could be seen emerging [23]. 


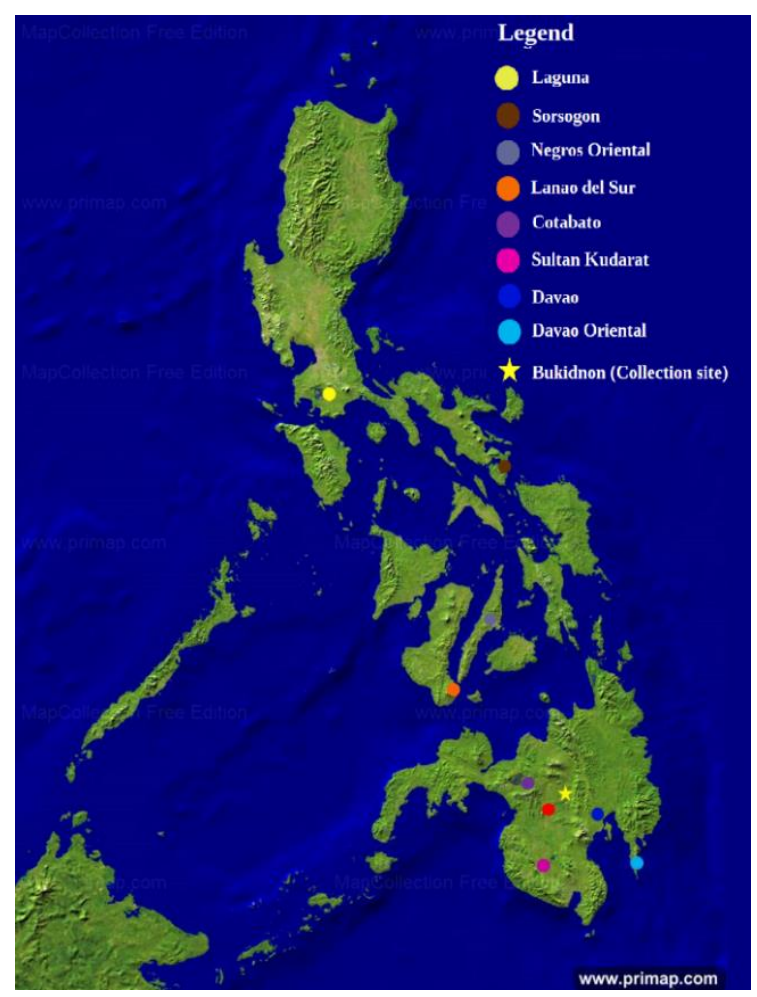

Figure 1. Map of the Philippines including the distributions and collection site of $H$. conoidea (Map source: Primap [25])

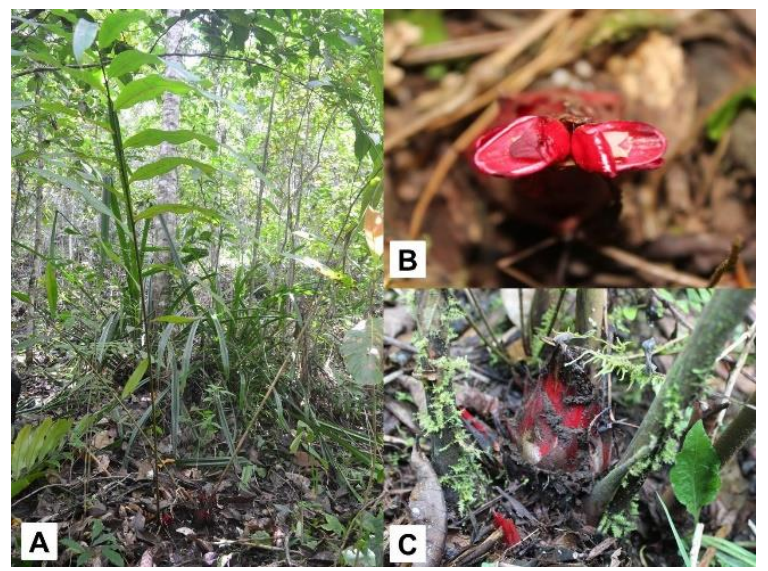

Figure 2. H. conoidea: Habit (a), inflorescence (b), and infructescence (c)

\section{Pollen tube growth}

Since in vitro germination is considered the best indicator of pollen viability [24], the pollen tube growth of $H$. conoidea was measured for a period of 2 weeks [18]. A total of three pollen per plate (nine pollen in total) were measured for every two days.The pollen was inoculated carefully from the petri plates to avoid contamination and examined under light microscope (LPO and HPO) for the measurement of tube and pollen tube lengths.

\section{Results and Discussion \\ Distribution and ethno-medicinal uses}

The distribution localities of $H$. conoidea in the different areas of the Philippines have rapidly increased from 2010 to present [see 4, 6] (Figure 1). However, threats such as habitat destruction, deforestation, burning of forests for farming and over collection have led to the decrease of their populations. Several populations of this species were observed by the main author in the nearby areas of Sibunga Falls in Kibawe, Bukidnon in 2014. However, during the conduct of this study to collect samples from the wild, no single population was found in said habitat. Thus, the samples utilized in this study were obtained from the ex situ conservation of Acma in 2010 (Figure 2). One reason of their depletion could be the deforestation in the area, since most trees which covered their populations were already cut down.

The uses of $H$. conoidea have long been recognized by the local people of Mindanao which they claim to cure different kinds of illnesses, such as diarrhea and stomach problems (fruits containing ripe seeds), fever and chills (rhizomes) and as condiments (leaves and rhizomes). In all field expeditions done by the authors, this plant either bore flowers and/or fruits and the reproductive parts were frequently visited by ants, which could be possible pollinator and the ripened fruits were eaten by rodents, which could be possible seed dispersal agent.

\section{Presence of starch in the pollen}

The test for the presence of starch revealed positive results, which agreed to the earlier report of Mendez et al. [18] that pollen of ginger species contained starch. Starchy pollen has been considered a feature of wind-pollinated (anemophilous) flowering plants, whereas insect-pollinated (entomophilous) species show a greater or lesser replacement of starch by sugar or lipids [26]. Positive starch reaction was categorized by Franchi et al. [27] in three color reactions - brown, blue and black. In the study of Wang et al. [28] on selected ginger species, starch reaction with IKI solution showed two colors (blue and black), and an unwanted phenomenon occurred with most or all pollen of Globba racemosa Sm., Zingiber striola- 


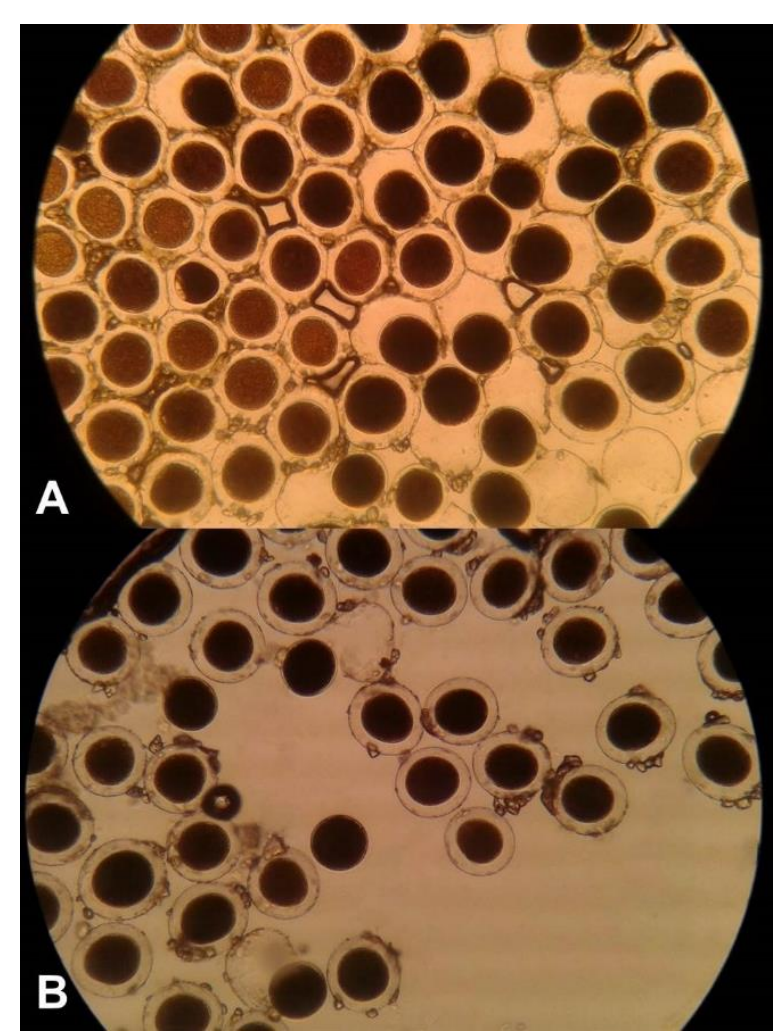

Figure 3. Pollen viability of $H$. conoidea under light microscope (100×): IKI solution (A) and af$\operatorname{ranin}(\mathrm{B})$

tum Diels., and a few pollen of Hedychium coronarium Koenig, Hornstedtia flavum and Hornstedtia spicatum Buch.-Ham. ex Smith stained red. On the other hand, the examined pollen of Etlingera dalican (Elmer) A.D.Poulsen and Etlingera philippinensis (Ridl.) R.M.Sm. of Mendez et al. [18] turned dark brown for the presence of starch.

All angiosperm pollen contains stored food reserves in the form of starch and/or lipids and can be classified in two classes: starchy and starchless [26]. Generally, the mean pollen diameter of the species with starchy pollen is significantly greater than that of the species with starchless pollen [29]. This present study, however, showed that there is no significant difference in size between starchy and starchless pollen in $H$. conoidea, although there are more variations in starchless pollen [28].

\section{Pollen viability}

The determination of pollen viability can be made using two basically different approaches namely, in-direct methods based on cytological parameters, such as color or staining pollen which are among the most reliable and widely used pollen viability tests [30,31, 32] or direct methods, such as the induction of in vitro $[10,11,33,34$, 35].

Using the test, the current study revealed that the percentage pollen viability of $H$. conoidea was higher in safranin test (92.43\%) and lower in iodine test (89.36\%) for the pollen which were examined right after collection. Whereas, the pollen which were stored for one week revealed lower pollen viability with $47.29 \%$ for safranin test and $33.14 \%$ for iodine test (Figure 3). Viability of pollen is extremely important for sexual reproduction of plants as reproduction success largely depends on the pollen dispersal and effective pollination within and between populations [36, 37, 38, 39]. However, pollen viability has been reported to be affected by several factors. It depends not only on its quality, but is also related to temperature, mineral nutrient and different plant growth regulators etc. in the germination environment [40]. Viability of pollen also mainly depends on relative atmospheric humidity at shedding and during pollen transport and pollen of different species need a high level of relative humidity to germinate [4147].

\section{Pollen germination and pollen tube growth}

Pollen viability can be assessed through in vitro germination. Pollen of some species can germinate in water [48], while other species require more complex media for germination [12]. The media used for in vitro germination of pollen of different species include simple sucrose/boric acid media to complex media [49]. In earlier studies, the most widely used medium for determining in vitro pollen germination and tube growth were agar, sucrose (with different types and concentrations) and boron [50, 51, 52]. The sugar used in the culture medium aimed to provide a balance between the osmotic solution and pollen germination [53], while agar added to such media provide stability, so that the growth of pollen tubes can be observed [54]. There are also several advantages of using agar in germination tests, such as the ease of taking carbohydrate, creating stable relative humidity and providing aerobic conditions [12].

For germination tests, a medium should also contain some nutrients (e.g., calcium, magnesium sulfate, potassium nitrate or boric acid) [35]. In vitro method for pollen germination and pollen tube growth could be particularly valuable in assessing the viability of stored $H$. conoidea pollen 


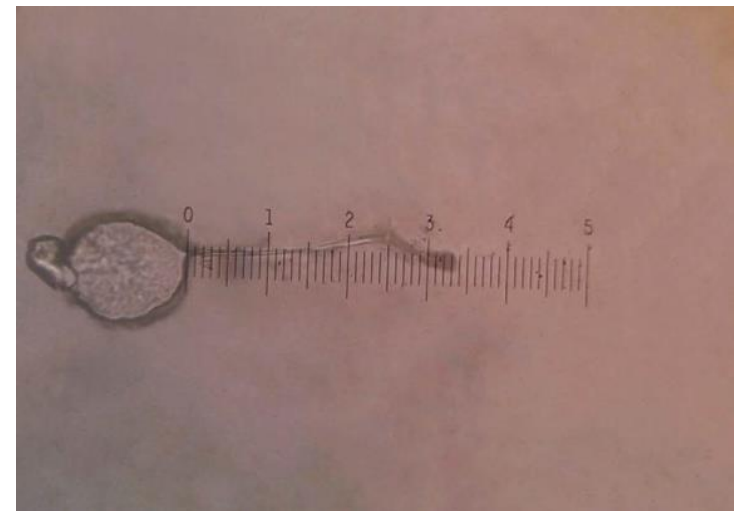

Figure 4. Pollen tube growth of $H$. conoidea under light microscope $(100 \times)$

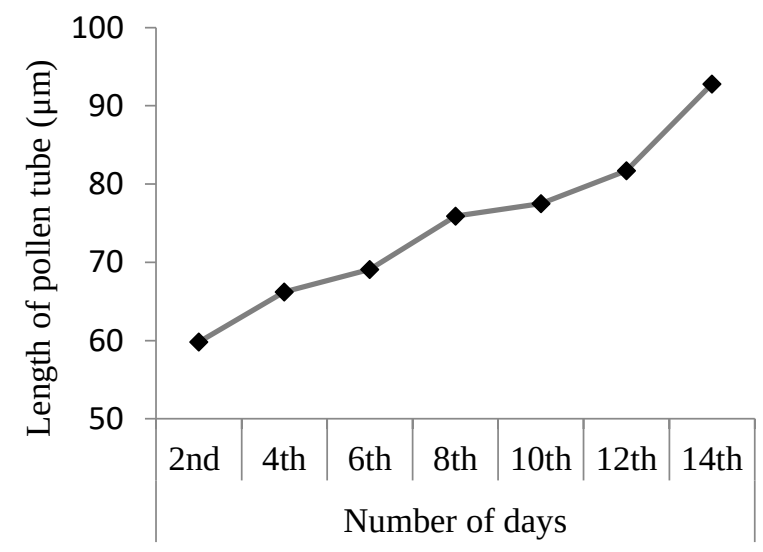

Figure 5. Length of pollen tube growth of $H$. conoidea monitored for two weeks

because in vitro pollen germination is a more reliable indicator of pollen viability [55, 56, 57]. In vitro pollen germination is also useful to detect alterations in germination or tube growth performance [58, 59, 60, 61].

In this study, the percentage germination of $H$. conoidea pollen was $72.65 \%$ after 24 hours of contact with agar medium and $11.13 \%$ after one week from initial plating (Figure 4). This study showed higher result compared to the data obtained by Mendez et al. [18] for the two Etlingera species. The higher percentage germination, imply that the pollen has more capacity to germinate and develop. This present study and the study of Mendez et al. [18] also support the field observations of Acma and Mendez [62] that among Etlingera dalican, Etlingera philippinensis, and $\mathrm{H}$. conoidea, the latter species often bore fruits, followed by $E$. dalican and rarely in E. philippinensis. For the pollen tube growth, it revealed that during the 2nd day of observation, the pollen tube lengths reached $58.4-61.2 \mu \mathrm{m}$, while in the $14^{\text {th }}$ day, pol- len tube lengths reached 94.4 - $97.2 \mu \mathrm{m}$ (Figure $5)$.

It is noteworthy that there are several factors that might affect the pollen germination and pollen tube growth in the examined $H$. conoidea pollen. One of which is the temperature, the very basic factor controlling the environmental conditions and influences pollen germination and longevity in stored pollen [63, 64, 65]. The pollen germination rate is also greatly influenced by the $\mathrm{pH}$ of germination medium, which has also been shown in several plant species [39, $66-71]$ and relative humidity and composition of the germination medium [72, 73]. Wang et al. [74] also concluded that boron has a regulatory role in pollen germination and pollen tube growth in Picea meyeri and the inhibition of pollen germination might also be affected by aluminum [75 - 79], in which the presence of aluminum was earlier reported by Acma and Mendez [62] in H. conoidea pollen.

Overall, the staining techniques in this study aimed to determine pollen enzymatic activity and membrane integrity, while in vitro germination assays determined the actual germination ability of pollen under suitable conditions [80, 81].

\section{Conclusion}

This study assessed pollen viability, in vitro pollen germination and pollen tube growth of $H$. conoidea, contributing to the knowledge of its reproductive biology and offer insights for conservation management and propagation protocols. Based on the results, it is concluded that $H$. conoidea pollen successfully germinated using agar medium and the viability can be stored for certain time. Knowledge regarding this study will be useful for plant breeding and conservation purposes, as this species is found in the wild, and up to now has been found only in the Philippines.

\section{Acknowledgment}

The authors are grateful to Prof. Heidi C. Porquis and Prof. Evangeline B. Sinamban for the supervision and guidance. Due acknowledgments are also given to Dr. Victor B. Amoroso, Dr. Reggie Y. Dela Cruz, Dr. Chris Rey M. Lituañas and Mr. Rainier A. Mendez for providing the chemicals and equipment needed for the study. Lastly, anonymous reviewers are thanked for their constructive comments. 


\section{References}

1. Larsen K, Larsen SS (2006) Gingers of Thailand. Chiang Mai, Queen Sirikit Botanic Garden.

2. Sakai S, Kato M, Inoue T (1999) Three pollination guilds and variation in floral characteristics of Bornean gingers (Zingiberaceae and Costaceae). American Journal of Botany 86 (5): $646-658$.

3. Zhang L, Li QJ, Deng XB et al. (2003) Reproductive biology of Alpinia blepharocalyx (Zingiberaceae): another example of flexistyly. Plant Systematics and Evolution 241 (1-2): 67 - 76. doi: 10.1007/s00606-003-0021-2.

4. Pelser PB, Barcelona JF, Nickrent DL (eds.) (2011) Co’s Digital Flora of the Philippines. http://www.philippineplants.org. Accessed date: 11 June 2018.

5. Lamb A, Gobilik J, Ardiyani M, Poulsen AD (2013) A guide to gingers of Borneo. Natural History Publications (Borneo). pp 1 -144 .

6. Acma FM (2010) Biosystematics of the genus Amomum Roxb (Family Zingiberaceae) in the Philippines. Ph.D. Thesis. University of the Philippines Los Baños.

7. Simpson M (2006) Plant systematics. New York, Academic Press.

8. Mildenhall D (2006) Hypericum pollen determines the presence of burglars at the scene of a crime: An example of forensic palynology. Forensic Science International 163 (3): 231 - 235. doi: 10.1016/j.forsciint.2005.11.028.

9. Khosh-Khui M, Bassiri A, Niknejad M (1976) Effects of temperature and humidity on pollen viability of six rose species. Canadian Journal of Plant Science 56 (3): 517 - 523. doi 10.4141/cjps76-085.

10. Acar I, Kakani VG (2010) The effects of temperature on in vitro pollen germination and pollen tube growth of Pistacia spp. Scientia Horticulturae 125 (4): 569 - 572. doi 10.1016/j.scienta.2010.04.040.

11. Alcaraz ML, Montserrat M, Hormaza JI (2011) In vitro pollen germination in avocado (Persea americana Mill.): Optimization of the method and effect of temperature. Scientia Horticulturae, 130 (1): 152 - 156. doi: 10.1016/j.scienta.2011.06.030.

12. Balatkova V (1974) Pollen biology. In: Stanley RG, Linskens HF (Eds.) Biochemistry management. Berlin Heidelberg New York, Springer-Verlag. pp 67.

13. Buyukkartal HN (2003) In vitro pollen germination and pollen tube characteristics in tetraploid red clover (Trifolium pratense L.). Turkish Journal of Botany 27: $57-61$.

14. Ahmad S, Rana A, Sharma R, Agnihotri RK (2012) Effect of different media and boric acid on pollen germination and tube of Tribulus terrestris - a traditional medicinal plant. International Journal of Pharmaceutical Sciences Review and Research 13 (2): 77 - 79.

15. Baloch MJ, Lakho AR, Bhutto H, Solangi MY (2001) Impact of sucrose concentration on in vitro pollen germination of Okra,
Hibiscus esculentus. Pakistan Journal of Biological Sciences 4 (4): 402-403. doi: 10.3923/pjbs.2001.402.403.

16. Karni L, Aloni B (2002) Fructokinase and hexokinase from pollen grains of bell pepper (Capsicum annuum L.): Possible role in pollen germination under conditions of high temperature and $\mathrm{CO}^{2}$ enrichment. Annals of Botany 90 (5): 607 - 612. doi: 10.1093/aob/mcf234.

17. Mendez NP, Porquis HC, Sinamban EB, Acma FM (2017) Comparative pollen viability and pollen tube growth of two endemic philippine Etlingera (Zingiberaceae, Alpinioideae). Philippine Journal of Systematic Biology 11 (2): 1 - 9.

18. Reddy KR, Kakani VG (2007) Screening Capsicum species of different origins for high temperature tolerance by in vitro pollen germination and pollen tube length. Scientia Horticulturae 112 (2): 130 - 135. doi: 10.1016/j.scienta. 2006.12.014.

19. Steiner W, Gregorius HR (1998) In vitro pollen germination experiments in Alnus and their relevance for mating system analysis. Forest Genetics 5 (1): 47 - 60 .

20. Tosun F, Koyuncu F (2007) Investigations of suitable pollinator for 0900 Ziraat sweet cherry cv: pollen performance tests, germination tests, germination procedures, in vitro and in vivo pollinations. Horticultural Science 34 (2): 47 - 53. doi: 10.17221/1851-HORTSCI.

21. Kakani VG, Prasad PVV, Craufurd PQ, Wheeler TR (2002) Response of in vitro pollen germination and pollen tube growth of groundnut (Arachis hypogaea L.) genotypes to temperature. Plant, Cell and Environment 25 (12): 1651 - 1661. doi: 10.1046/j.1365-3040.2002.00943.x.

22. Gandadikusumah VG, Wawangningrum H, Rahayu S (2017) Pollen viability of Aeschynanthus tricolor Hook. The Journal of Tropical Life Science 7(1): 53 - 60. doi: 10.11594/jtls.07.01.09.

23. Rodriguez-Enriquez MJ, Mehdi S, Dickinson HG, GrantDowntown RT (2012) A novel method for efficient in vitro germination and tube growth of Arabidopsis thaliana pollen. New Phytologist 197 (2): 668 - 679. doi: 10.1111/nph.12037.

24. Shivanna KR, Linskens HF, Cresti M (1991) Pollen viability and pollen vigor. Theoretical and Applied Genetics 81 (1): 38 42. doi: 10.1007/BF00226109.

25. Primap (2018) National maps - Philippines - Satellite 1187x1600. http://www.primap.com/. Accessed date: September 2018.

26. Baker HG, Baker I (1979) Starch in angiosperm pollen grains and its evolutionary significance. American Journal of Botany 66 (5): 591 - 600. doi: 10.2307/2442509.

27. Franchi GG, Bellani L, Nepi M, Pacini E (1996) Types of carbohydrate reserves in pollen: Localization, systematic distribution and ecophysiological significance. Flora 191 (2): 143 - 159. doi: 10.1016/S0367-2530(17)30706-5.

28. Wang YQ, Zhang DX, Che ZY (2004) Pollen histochemistry and pollen: Ovule ratios in Zingiberaceae. Annals of Botany 94 (4): 583 - 591. doi:10.1093/aob/mch177. 
29. Grayum MH (1985) Evolutionary and ecological significance of starch storage in pollen of the Araceae. American Journal of Botany 72 (10): 1565 - 1577. doi: 10.2307/2443307.

30. Cresti M, Tiezzi A (1992) Sexual plant reproduction. In Pierson ES, Li YQ (Eds.) The cytoskeleton of pollen grains and pollen tube. Berlin, Springer-Verlag. pp 99 - 113. doi: 10.1007/2F9783-642-776779_10.

31. Abdelgadir HA, Johnson SD, Van Staden J (2012) Pollen viability, pollen germination and pollen tube growth in the biofuel seed crop Jatropha curcas (Euphorbiaceae). South African Journal of Botany Pretoria 79: 132 - 139. doi: 10.1016/j.sajb.2011.10.005.

32. Burke IC, Wilcut JW, Allen NS (2007) Viability and in vitro germination of Johnson grass (Sorghum halepense) pollen. Weed Technology 21 (1): 23 - 29. doi: 10.1614/WT-05-171.1.

33. Diaz SL, Garay BR (2008) Simple methods for in vitro pollen germination and pollen preservation of selected species of genus Agave. e-Gnosis 6 (2): 1 - 7.

34. Sakhanokhoa HF, Rajasekaran K (2010) Pollen biology of ornamental ginger (Hedychium spp. J. Koenig). Scientia Horticulturae 125 (2): 129 - 135. doi: 10.1016/j.scienta.2009.12.037.

35. Soares TL, de Oliveira e Silva S, de Carvalho Costa MAP et al. (2008) In vitro germination and viability of pollen grains of banana diploids. Crop Breeding and Applied Biotechnology 8: 111 - 118. doi: 10.12702/1984-7033.v08n02a03.

36. Wronska-Pilarek D, Tomlik-Wyremblewska A (2010) Pollen viability and in vitro germination of selected Central European species from genus Rosa analysed with different methods. Dendrobiology 64: 43 - 53.

37. Batos B, Nikolić BM (2013) Variability of in vitro germination of Picea omorica pollen. Dendrobiology 69: 13 - 19. doi 10.12657/denbio.069.002.

38. Soares TL, de Jesus ON, dos Santos-Serejo JA, de Oliveira EJ (2013) In vitro pollen germination and pollen viability in passion fruit (Passiflora spp.). Revista Brasileira de Fruticultura 35 (4): 1116 - 1126. doi: 10.1590/S0100-29452013000400023.

39. Mourelle D, Gaiero P, Speroni G, Millán C et al. (2016) Comparative pollen morphology and viability among endangered species of Butia (Arecaceae) and its implications for species delimitation and conservation. Palynology 40 (2): 160 - 171. doi: 10.1080/01916122.2014.999955.

40. Qiu DL, Liu XH, Guo SZ (2005) Effects of simulated acid rain on fertility of litchi. Journal of Environmental Sciences 17 (6): $1034-1037$.

41. Frankel R, Galun E (1977) Pollination mechanisms, reproduction and plant breeding. New York, Springer.

42. Pacini E (1990) Harmomegathic characters of Pteridophyta spores and Spermatophyta pollen. In: Heese M, Ehrendorfer F (Eds.) Morphology, Development and Systematic Relevance of Pollens and Spores. Plant Systematics and Evolution. pp 53 69. doi: 10.1007/978-3-7091-9079-1_5.
43. Paoletti E (1992) Effects of acidity and detergent on in vitro pollen germination and tube growth in forest tree species. Tree Physiology 10 (4): 357 - 366. doi: 10.1093/treephys/10.4.357.

44. Corbet SA, Plumridge JR (1985) Hydrodynamics and the germination of soil-seed rape pollen. Journal of Agricultural Science 104 (2): 445 - 451. doi: 10.1017/S0021859600044154.

45. Digonnet-Kerhoas C, Gay C (1990) Qualite' du pollen: Definition et estimation. Bulletin. Bulletin de la Société Botanique de France. Actualités Botaniques 137 (2): 97 - 100. doi: 10.1080/01811789.1990.10827004.

46. Mulugeta D, Maxwell BD, Fay PK, Dyer WE (1994) Kochia (Kochia scoparia) pollen dispersion, viability and germination. Weed Science 42 (4): 548 - 552.

47. Loupassaki M, Vasilakakis M (1995) The effect of temperature and relative humidity on the in vitro germination of the pollen of avocado. In Proceeding of the $3^{\text {rd }}$ World Avocado Congress. pp $42-45$.

48. Duffield JW (1954) Studies of extraction, storage and testing of pine pollen. Zeit Forstgen. Forstpflanz 3: 39 - 45

49. Jayaprakash P, Sarla N (2001) Development of an improved medium for germination of Cajanus cajan (L.) Millsp. pollen in vitro. Journal of Experimental Botany 52 (357): 851 - 855. doi: 10.1093/jexbot/52.357.851.

50. Miranda PA, Clement CR (1990) Germination and storage of pejibaye (Bactris gasipaes) palmae pollen. Revista de Biología Tropical 38 (1): 29 - 33.

51. Derin K, Eti S (2001) Determination of pollen quality, quantity and effect of cross pollination on the fruit set and quality in the pomegranate. Turkish Journal of Agriculture and Forestry 25: $169-173$.

52. Ercisli S (2007) Determination of pollen viability and in vitro pollen germination of Rosa dumalis and Rosa villosa. Bangladesh Journal of Botany 36 (2): 185 - 187. doi: 10.3329/bjb.v36i2.1511.

53. Loguercio LL (2002) Pollen treatment in high osmotic potential: A simple tool for in vitro preservation and manipulation of viability in gametophytic populations. Brazilian Journal of Plant Physiology 14 (1): 65 - 70. doi: 10.1590/S167704202002000100009.

54. Martin FW (1972) In vitro measurement of pollen tube growth inhibition. Plant Physiology 49 (6): 924 - 925. doi: 10.1104/pp.49.6.924

55. Heslop-Harrison J (1979) Aspects of the structure, cytochemistry and germination of the pollen of rye (Secale cereale L.). Annals of Botany 44 (Suppl. 1): 2 - 47.

56. Heslop-Harrison J, Heslop-Harrison Y, Shivanna KR (1984) The evolution of pollen quality, and a further appraisal of the fluorochromatic (FCR) test procedure. Theoretical and Applied Genetics 67 (4): 367 - 375. doi: 10.1007/BF00272876.

57. Stone JL, Thomson JD, Dent-Acosta SJ (1995) Assessment of pollen viability in hand-pollination experiments: A review. 
American Journal of Botany 82 (9): 1186 - 1197. doi: 10.1002/j.1537-2197.1995.tb11591.x.

58. Cole RA, Synek L, Zarsky V, Fowler JE (2005) SEC8, a subunit of the putative Arabidopsis exocyst complex, facilitates pollen germination and competitive pollen tube growth. Plant Physiology 138: 2005 - 2018. doi: 10.1104/pp.105.062273.

59. Hashida SN, Takahashi H, Kawai-Yamada M, Uchimiya H (2007) Arabidopsis thaliana nicotinate/nicotinamide mononucleotide adenyltransferase (AtNMNAT) is required for pollen tube growth. The Plant Journal 49 (4): 694 - 703. doi: 10.1111/j.1365-313X.2006.02989.x.

60. Procissi A, Guyon A, Pierson ES et al. (2003) KINKY POLLEN encodes a SABRE-like protein required for tip growth in Arabidopsis and conserved among eukaryotes. The Plant Journal 36 (6): 894 - 904. doi: 10.1046/j.1365-313X.2003.01933.x.

61. Steinebrunner I, Wu J, Sun Y et al. (2003) Disruption of apyrases inhibits pollen germination in Arabidopsis. Plant Physiology 131: 1638 - 1647. doi: 10.1104/pp.102.014308.

62. Acma FM, Mendez NP (2018) Pollen morphology and pollen elemental composition of selected philippine native gingers in tribe Alpinieae (Alpinioideae: Zingiberaceae). Biological Forum - An International Journal 10 (1): 1 - 10.

63. Sanzol J, Herrero M (2001) The "effective pollination period in fruit” trees. Scientia Horticulturae $90(1-2): 1$ - 17. doi: 10.1016/S0304-4238(00)00252-1.

64. Aparecida SPL, Darla RJ, Pasqual M et al. (2004) Receptiveness of the stigma and in vitro germination of orange pollen, submitted to different temperature. Ciência e Agrotecnologia 28 (5): 1087 - 1091. doi: 10.1590/S141370542004000500016 .

65. Sharafi Y (2010) Suitable in vitro medium for studying pollen viability in some of the Iranian hawthorn genotypes. Journal of Medicinal Plants Research 4 (19): 1967 - 1970. doi: 10.5897/JMPR10.419.

66. Henny RJ (1977) Effect of sucrose level, medium composition and $\mathrm{pH}$ on the in vitro germination of pollen from Spathiphyllum floribundum (Linden \& Andre). N.E. Br. Mauna Loa and Vriesea Malzinei E. Morr. Proceedings of the Florida State Horticultural Society 90: $304-306$.

67. Bellani LM, Rinallo C, Muccifora S, Gori P (1997) Effects of simulated acid rain on the pollen physiology and ultrastructure in apple. Environmental Pollution 95 (3): 357 - 362. doi: 10.1016/S0269-7491(96)00127-3.

68. Abraitiene A, Zvingila D, Kuusiene S (2003) Pollen susceptibility to acidification and DNA polymorphism of Scots pine (Pinus sylvestris L.) plus trees. Ekologija (Vilnius) 1: 51 54.
69. Munzuroglu O, Obek E, Gecgil H (2003) Effects of simulated acid rain on the pollen germination and polen tube growth of apple (Malus sylvestris Miller cv. Golden). Acta Biologica Hungarica 54 (1): 95 - 103. doi: 10.1556/ABiol.54.2003.1.10.

70. Burke JJ, Velten J, Oliver MJ (2004) In vitro analysis of cotton pollen germination. Agronomy Journal 96 (2): 359 - 368. doi: 10.2134/agronj2004.3590.

71. Mbogning JBD, Youmbi E, Nkongmeneck BA (2007) Morphological and in vitro germination studies of pollen grains in kola tree (Cola sp.). Akdeniz Universitesi Ziraat Fakultesi Dergisi 20 (2): 311 - 318.

72. Adhikari KN, Campbell CG (1998) In vitro germination and viability of buckwheat (Fagopyrum esculentum Moench) pollen. Euphytica 102 (1): 87 - 92. doi: 10.1023/A:1018393425407.

73. Rossel P, Herrero M, Galan Sauco V (1999) Pollen germination of cherimoya (Annona cherimola Mill): in vivo characterization and optimization of in vitro germination. Scientia Horticulturae 81 (3): 251 - 265. doi: 10.1016/S0304-4238(99)00012-6.

74. Wang Q, Lu L, Wu X, Li Y, Lin J (2003) Boron influences pollen germination and pollen tube growth in Picea meyeri. Tree Physiology 23 (5): 345 - 351. doi: 10.1093/treephys/23.5.345.

75. Reiss HD, Herth W (1985) Nifedipine-sensitive calcium channels are involved in polar growth of lily pollen tubes. Journal of Cell Science 76: 247 - 254.

76. Searcy KB, Mulcahy DL (1990) Comparison of the response to aluminum toxicity in gametophyte and sporophyte of four tomato (Lycopersicon esculentum Mill.) cultivars. Theoretical and Applied Genetics 80 (3): 289 - 295. doi: 10.1007/BF00210062.

77. Obermeyer G, Weisenseel MH (1991) Calcium-channel blocker and calmodulin antagonists affect the gradient of free calcium ions in lily pollen tubes. European Journal of Cell Biology 56 (2): $319-327$.

78. Malho R, Read ND, Trewavas AJ, Pais MS (1995) Calcium channel activity during pollen tube growth and reorientation. The Plant Cell 7: 1173-1184.

79. Sawidis T, Reiss HD (1995) Effects of heavy metals on pollen tube growth and ultrastructure. Protoplasma 185 (3 - 4): 113 122. doi: 10.1007/BF01272851.

80. Tuinstra MR, Wedel J (2000) Estimation of pollen viability in grain sorghum. Crop Science 40 (4): 968 - 970. doi: 10.2135/cropsci2000.404968x.

81. Lyra DH, Sampaio LS, Pereira DA et al. (2011) Pollen viability and germination in Jatropha ribifolia and Jatropha mollissima (Euphorbiaceae): Species with potential for biofuel production. African Journal of Biotechnology 10 (3): 368 - 374 